\title{
Bending properties of Norway spruce timber. Comparison between fast- and slow-grown stands and influence of radial position of sawn timber
}

\author{
I. Robert Kliger*, Mikael Perstorper, Germund Johansson
}

Chalmers University of Technology, Department of Structural Engineering, Division of Steel and Timber Structures, SE-412 96 Göteborg, Sweden

(Received 5 November 1996; accepted 25 November 1997)

\begin{abstract}
The primary objective of this work was to study one aspect of improving timber quality. The aim of this paper is to supplement previously published results in Wood Science and Technology. Bending strength and stiffness of Norway spruce (Picea abies) from three stands in southern Sweden, two fast-grown and one slow-grown, were measured. Radial variations were studied using six studs $(45 \mathrm{~mm} \times 70 \mathrm{~mm} \times 2900 \mathrm{~mm}$ ) per log cut along a diameter, with a total of 500 studs. The bending strength of studs from the slow-grown stand was $57 \%$ higher and the modulus of elasticity $54 \%$ higher than that of the fast-grown stands. The bending strength of studs from mature wood (near the bark) was $47 \%$ higher and modulus of elasticity $30 \%$ higher than that of the core studs. The improvement in mechanical properties from pith to bark was far more significant for the studs from the slow-grown stand than from the fast-grown ones. (C) Inra/Elsevier, Paris.)
\end{abstract}

\section{Norway spruce / strength / stiffness / mechanical performance}

Résumé - Propriétés de flexion de l'épicéa commun. Comparaison entre sites à croissance rapide et lente et influence de la position radiale des sciages. L'objectif premier de ce travail est l'étude de paramètres importants contrôlant la qualité des sciages. Cette étude complète des résultats publiés précédemment. La résistance et la rigidité en flexion de l'épicéa commun (Picea abies) provenant de trois sites du sud de la Suède, deux à croissance rapide et un à croissance lente, ont été mesurées. Pour l'étude des variations radiales, six débits $(45 \times 70 \times 2900 \mathrm{~mm})$ ont été effectués le long d'un diamètre pour chaque grume, avec un total de 500 débits. La résistance en flexion et le module d'élasticité étaient respectivement 57 et $54 \%$ plus élevés pour les débits provenant d'un site à croissance lente que pour ceux provenant d'un site à croissance rapide, et respectivement 47 et $30 \%$ plus élevés pour les débits près de la périphérie que pour ceux qui sont

\footnotetext{
* Correspondence and reprints

E-mail: robert.kliger@ste.chalmers.se
} 
près du cœur. L'amélioration des propriétés mécaniques du cœur à la périphérie était bien plus significative pour les débits du site à croissance lente que pour ceux des sites à croissance rapide. (c) Inra/Elsevier, Paris.)

\section{épicéa commun / résistance / rigidité / propriétés mécaniques}

\section{INTRODUCTION}

The position of timber products in the competition with other load-carrying building materials depends to a large extent on a knowledge of their mechanical properties. Relationships between the raw material parameters and strength and stiffness, as well as their variability within a stand, a species, a tree or a $\log$, are at present unknown or unclear. For the timber production and construction industries, it is highly beneficial to know which material parameters are of importance to the structural performance of sawn timber when grading or selecting the raw material. The structure of the timber industry with its predominance of small companies has prevented the development of methods for selecting the raw material to produce high-quality products in terms of their structural performance, as these companies are often not aware of the needs of end-users. As a result, we should first try to understand how and why various raw materials affect the structural performance before attempting to improve some products or develop new ones.

The most basic requirements for any material used in engineered construction are that it should have sufficient strength to guarantee the desired level of structural safety and sufficient stiffness to meet the stability requirements and any desirable serviceability criteria. The main disadvantage of timber as an engineering material is that it does not have consistent, predictable, reproducible and uniform properties. The great variability between individual trees, as well as within and between stands, indicates that there is large potential for more efficient and optimized forest and $\log$ utilization. In an ideal 'enduse-oriented' system, each stand, each tree and each part of the stem should be given a destination for an end product in terms of an optimum end use. However, forest management techniques, which optimize the volume of fibre which is produced, have been implemented with little regard for the compatibility between the wood properties that are produced and the end use. In order to make the most rational use of the timber from intensively managed forests in particular, appropriate information on the properties of the material needs to be available.

The fact that variations in conifer wood exist and are dependent on growth conditions has been established by many scientists in the past ([1-3, 10,15]; among others). However, these variations are not used to create advantages for timber products and produce the 'right' products with the 'right' properties for the 'right' end use in a positive manner. The variability of wood properties can have both positive and negative effects, depending on how it is used [8]. The amount of work that is carried out on the mechanical properties of timber from conifers is too voluminous to be included in this journal. However, systematic comparisons of mechanical properties and existing variations in material properties and sawing patterns are lacking. In recent years and in various parts of the world, a great deal of work has been carried out to develop models in order to predict various properties of sawn timber from known agricultural regimens $[5,12$, 16-18]. Shivnaraine [14] and Kretschmann and Bendtsen [9] studied the effect of juvenile wood on the bending properties of structural size timber. The 
radial variation in mechanical properties was considerably less pronounced than that found in studies of clear wood. The grain distortions around knots appear to diminish the effects of juvenile wood found in clear wood. The linking of wood properties and grading rules for various end uses is fundamental for the future development of the sawing simulation system.

The primary objective of this paper is to show how a radial position in a tree affects strength and stiffness. Furthermore, the relationships between the strength and stiffness and between some growth characteristics and strength and stiffness are shown. The results of these findings can be applied first by the forest industry by allocating the 'right' raw material to the 'right' industry and second by the sawmills to obtain a better basis for choosing raw materials and/or sawing patterns in order to produce structural timber with the optimum mechanical properties for the intended end use. Furthermore, this paper presents information and data related to the effects of the raw material parameters on the mechanical bending properties of structural timber.

\subsection{Scope of two studies presented in this paper}

This paper consists of some results obtained during two parallel studies conducted at Chalmers University of Technology in recent years on studs measuring $45 \times 70 \times 2900$ (in mm) from Norway spruce (Picea abies) grown in southern Sweden. The first study, already reported by Perstorper et al. [13] and Kliger et al. [7], was based on material from two stands of fast-grown Norway spruce, see figure 1 . However, only the data from the first stand are used in this paper, as they are sufficient to make a comparison with the data obtained in the second study. The second study was based on material from one stand of slow-grown Norway spruce [6]. However, this second study was limited compared with the first one. Only studs from the butt logs, cf. figure I, were included and fewer parameters were measured (knot area ratio was not measured, for example).

In this paper, the results obtained in both studies are combined and joint conclusions have been drawn. In general, it is shown how the modulus of elasticity, $\mathrm{E}\left(\mathrm{E}_{\text {edge }}\right)$ and the bending strength, $\mathrm{f}_{\mathrm{m}}$ (sometimes referred to as MOR in the literature), in studs varies according to:

a) position in the stem, i.e. in the radial direction - the difference between studs sawn close to the pith and further away from the pith of the butt log; based on studs from both fast-grown and slowgrown stands;

b) the variation in wood density (DENS), ring width (RW), grain angle (GA) and knot area ratio (KAR), where $\mathrm{KAR}$ is based on studs from fast-grown stands alone.

\section{MATERIALS AND METHODS}

\subsection{Specimen preparation}

\subsubsection{Fast-grown stands}

For a more detailed description of the two fast-grown stands, see Perstorper et al. [13]. However, a brief summary of the most important issues related to this paper is presented here. All the timber used in this study came from a relatively fast-grown stand, about 65 years old, which contained large trees $(\mathrm{dbh} \approx$ $360 \mathrm{~mm}$ ). These trees had been planted on land where animals had previously grazed. Log sampling, the number of logs from each stand, sawing patterns and notations are shown in figure 1. Two sets of logs were taken from the butt end (lower part of the large diameter butt logs - LBL, upper part of the large diameter butt $\operatorname{logs}$ - UBL) and one set from near the top (TL, not included in this paper) of the fast-grown trees (see figure $I$ ). Beams from these logs 
[measuring $70 \times 290 \times 2900$ (in mm)] from the butt end were sawn from the central part of each log (containing the pith), dried and ripped prior to being equilibrated to $12 \% \mathrm{MC}$. Six studs were sawn from each beam from the butt. In all, 249 studs from butt logs (both LBL and UBL) were used for evaluation from this stand. Three studs from position 1 and 6 (mature wood) were missing (failure due to handling or during measurements of the modulus of elasticity).

\subsubsection{Slow-grown stand}

All the timber used in the second study came from a slow-grown stand of large-diameter trees $(\mathrm{dbh}=400 \mathrm{~mm})$. This stand (probably self-seeded) was about 105 years old. For different reasons, it was only possible to take two sets of logs from the butt end (lower part of butt logs - LBL, upper part of the large diameter butt logs - UBL) in the same manner as the logs from fast-grown trees, cf. figure 1 . As a result, only the radial variation was studied from the material obtained in the second study. In the same way as for the butt logs from fastgrown trees, six studs were sawn from each beam and a total of 251 studs was obtained. One stud from position 4 was missing (failure during measurements of the modulus of elasticity).

\subsection{Modulus of elasticity, $E$ and bending strength}

Different methods were used for measuring the modulus of elasticity in each study. It was not possible to comply with the test standards for many reasons. In order to compare different E-values for all the members, including some large-beam members (not included in both these studies mentioned in this paper), it was necessary to measure the curvature over the same distance. This means that the length to depth ratio had to vary (in the first study) between studs and some large beams used in parallel studies during this period.

In the first study (studs from two fast-grown stands), an hydraulic jack was used to load all the specimens using the test set-up shown in figure $2 A$. As a result, the load versus curvature was plotted continuously. The maximum load corresponded to a bending stress value of no more than $10 \mathrm{MPa}$. In the second study (studs from the slow-grown stand), two different dead weights were applied to the specimens using the test set-up shown in figure $2 B$. These loads corresponded to a bending stress value of 2 and $5 \mathrm{MPa}$. However, despite the two different ways of loading, the length over the constant moment area and the measurements of the curvature over a length of $1 \mathrm{~m}$ were the same for all the specimens in both studies, see figure 2 .

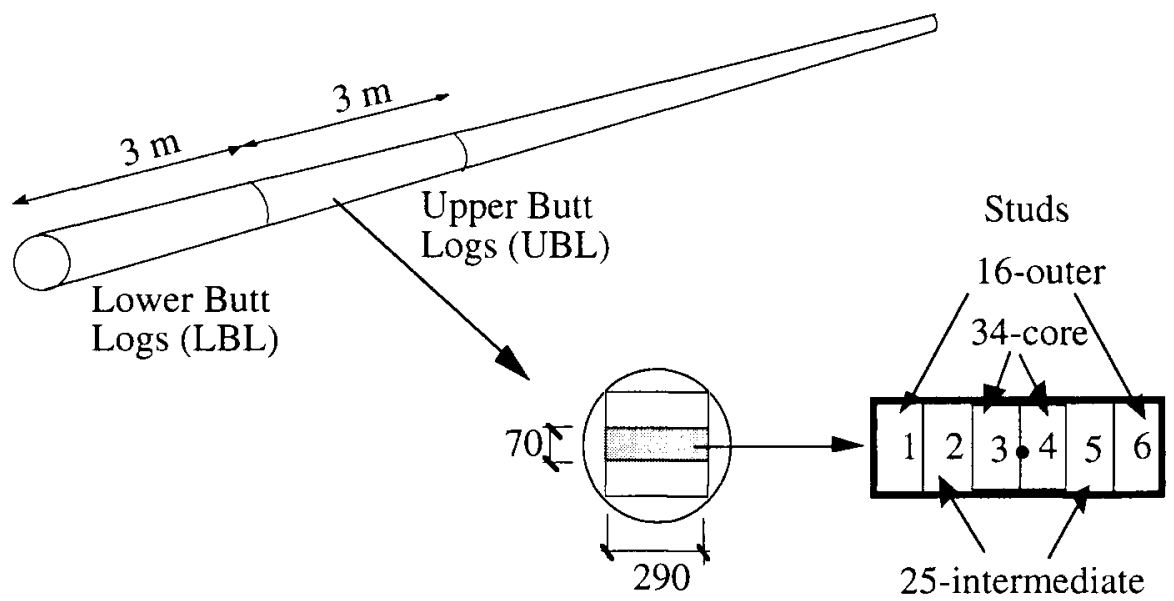

Figure 1. Log sampling, cross-sections, notations of log types and of each stud - fast-grown stands. 

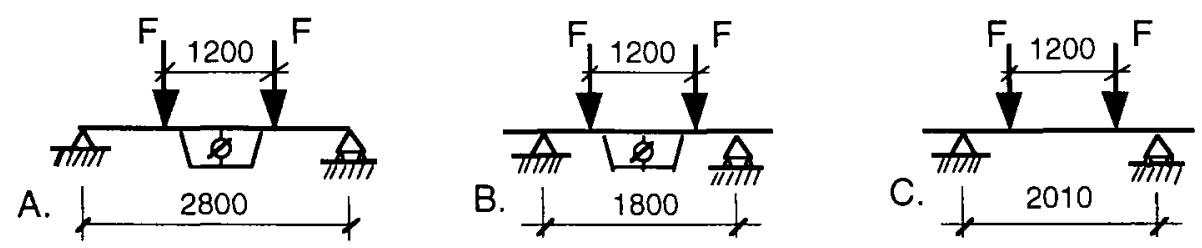

Figure 2. Test set-up for measurement of mechanical properties in bending. A) Modulus of elasticity, E - studs from fast-grown stands; B) modulus of elasticity, E - studs from slow-grown stand; C) short-term bending strength, $\mathrm{f}_{\mathrm{m}}-$ all studs.

As a result, this difference in the experimental procedure has not effected the comparison of studs from fast-grown and slow-grown stands.

\subsection{Measurements of the short-term bending strength, fm}

The distance between the concentrated loads was kept the same as that used when the measurements of the modulus of elasticity were made. However, the total span was shortened for bending strength measurements in comparison with measurements of the modulus of elasticity for studs from fast-grown stands to avoid overly large deformation and possible second-order effects, figure $2 C$. No studs failed in shear. As a result of the so-called length effect [ 11$]$, the strength values were most probably slightly lower than they would have been if the standard test set-up had been used. However, all the material was tested in the same way. Both mechanical properties in this study were obtained by applying a constant moment to a length (figure 2) which is much longer than that recommended in standard procedure, i.e. 17 times the depth compared with 6 times the depth (equal to one-third of the total span of specimens).

Moisture content, density, position of the pith and mean ring width values were obtained prior to the tests to failure for all studs. The average moisture content was 12.2 and $11.8 \%$ for studs from fast-grown and slowgrown stands, respectively. As a result, density and bending strength were not adjusted owing to these small deviations from a $12 \%$ moisture content. Four studs (three fast-grown and one slow-grown) failed owing to handling or during measurements of $\mathrm{E}$.
It should also be pointed out that no grading whatsoever was performed prior to testing. All the studs were included in the analysis, irrespective of severe cracks, slope of grain, compression wood, large knots and so on. The strength properties of graded material would probably be different, especially for the lower tails of the distributions. This is also the reason why the 5th percentile for bending strength was not evaluated.

\section{RESULTS}

\subsection{General}

There was no significant difference when comparing the respective values for the lower and upper butt logs from the same spatial position. Consequently, when the variation in the radial direction is considered, the lower and upper butt logs were treated statistically as the same type of butt $\log (\mathrm{BL})$. This was valid for studs from both fast-grown (FG) and slowgrown stands (SG).

The linear regression for all studs $(n=500)$ is shown in figure 3 . The regression coefficient, $\mathrm{R}=0.83$, is almost the same as that previously reported for the same species by Johansson et al. [4], for example. The relationship between bending strength and modulus of elasticity was found by Johansson et al. [4] to be $f_{m}=-2.4+3.8 E_{m}$ and is the basis for setting values for grading machines in Sweden. Some general results distinguishing each stand [including butt logs (BL), top 


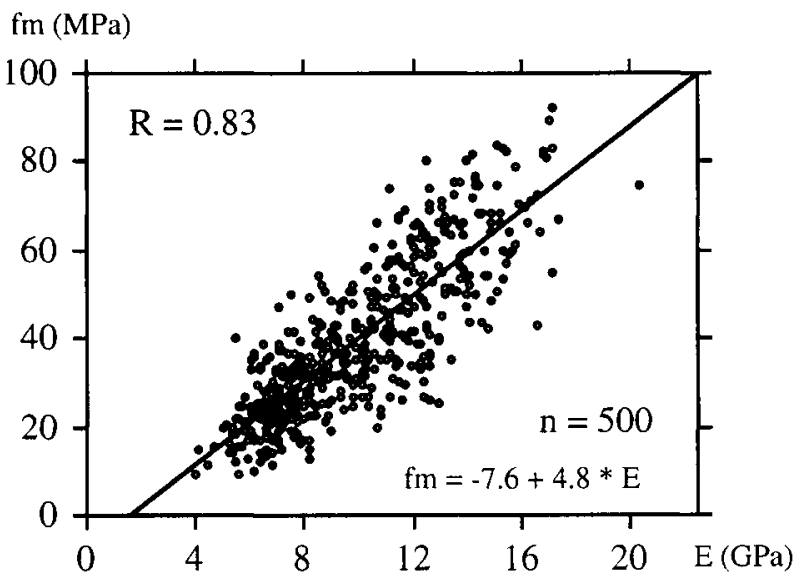

Figure 3. Linear regression between bending strength $\left(\mathrm{f}_{\mathrm{m}}\right)$ and modulus of elasticity $(\mathrm{E})$ based on all studs.

logs (TL) from fast-grown stands (FG) and thinning stand (ThL)] in terms of the measured mean values for strength $\left(f_{m}\right)$, modulus of elasticity (E), density (DENS) and ring width (RW) are shown in table 1 .

\subsection{Variations in the radial direction according to stud groups}

The radial position in these studies is expressed in three stud groups, i.e. core studs (34), intermediate studs (25) and mature studs (16), cf. figure 1. These stud groups are compared for butt logs only, i.e from the fast-grown stands (FG-BL) and from the slow-grown stand (SG-BL). Both stands are represented by about 250 studs and each stud group (i.e. core, intermediate and mature) in each stand is represented by about 84 studs. A summary of these variations is shown in figures 4-6. The mean values for each group and the statistical significance (unpaired $t$-test) when comparing these groups are shown in table II.

It was found that the mean values for both $\mathrm{f}_{\mathrm{m}}$ and $\mathrm{E}$ were lowest for the core studs (group 34) and increased further away from the pith (groups 25 and 16). Each stud group was statistically differ- ent from the others when it came to bending strength and stiffness, cf. table II. However, it appears that the difference between stud groups 25 and 34 from the fast-grown stand was not statistically significant when it comes to strength. Furthermore, the standard deviation for both $\mathrm{f}_{\mathrm{m}}$ and $\mathrm{E}$ appears to be smaller nearest to the pith; see figures 5 and 6 , where the cumulative distribution in per cent clearly demonstrates that there is no difference between groups 25 and 34 up to the $80 \%$ percentile for the fast-grown material.

The radial variation in bending strength $\left(f_{m}\right)$ and the modulus of elasticity $(E)$, based on the division into stud groups, is shown in figure 4 . The corresponding variation in density and ring width is shown in figure 7 . The mean value for the modulus of elasticity was significantly higher in the core studs from the slow-grown stand than in the studs from all groups (including those from the mature wood) from the fast-grown stand. The same thing applies to bending strength, but the difference between the core studs from the slowgrown stand (34) and the studs from the mature wood (16) from the fast-grown stand was not statistically significant.

The distribution of strength $\left(f_{m}\right)$ for the studs from the butt logs divided into 
Table I. Bending strength $\left(f_{m}\right)$, modulus of elasticity (E), density (DENS) and ring width (RW) - mean values and standard deviation in brackets (Stdv).

\begin{tabular}{lcccc}
\hline $\begin{array}{l}\text { Properties } \\
\text { No. of studs: }\end{array}$ & $\begin{array}{l}\text { FG-BL } \\
n=248\end{array}$ & $\begin{array}{l}\text { FG-TL } \\
n=56\end{array}$ & $\begin{array}{c}\text { ThL } \\
n=62\end{array}$ & $\begin{array}{c}\text { SG-BL } \\
n=251\end{array}$ \\
\hline $\mathrm{f}_{\mathrm{m}}(\mathrm{MPa})$ & $30.9(12.3)$ & $31.4(7.2)$ & $35.4(8.9)$ & $48.4(17.4)$ \\
$\mathrm{E}(\mathrm{GPa})$ & $7.8(1.8)$ & $9.0(1.2)$ & $8.2(1.4)$ & $12.0(2.5)$ \\
$\mathrm{DENS}^{\mathrm{a}}\left(\mathrm{kg} \mathrm{m}^{-3}\right)$ & $389(34)$ & $451(33)$ & $411(24)$ & $444(35)$ \\
$\mathrm{RW}^{\mathrm{b}}(\mathrm{mm})$ & $5.4(1.7)$ & $3.8(0.9)$ & $5.7(1.0)$ & $3.2(1.0)$ \\
\hline
\end{tabular}

${ }^{a}$ Density (DENS) was based on volume and weight at $12 \%$ moisture content (MC); ${ }^{h}$ ring width (RW) was represented by a mean value of five annual rings.

Table II. Radial variation in strength and stiffness and in some properties of growth characteristics.

\begin{tabular}{|c|c|c|c|c|c|c|c|}
\hline Properties & Core (34) & Interm. (25) & $\begin{array}{l}\text { Mean values } \\
\text { Mature (16) }\end{array}$ & (unit) & $16-25$ & $\begin{array}{c}P \text {-values } \\
16-34\end{array}$ & $25-34$ \\
\hline \multicolumn{8}{|c|}{ Fast-grown stand, butt logs (FG - BL) } \\
\hline & No.: 84 & 84 & 81 & & & & \\
\hline $\mathrm{f}_{\mathrm{m}}$ & 27.2 & 28.9 & 36.8 & (MPa) & 0.002 & $<0.0001$ & 0.259 \\
\hline $\mathrm{E}$ & 7.09 & 7.62 & 8.68 & $(\mathrm{GPa})$ & 0.004 & $<0.0001$ & 0.019 \\
\hline DENS & 390 & 381 & 395 & $\left(\mathrm{~kg} / \mathrm{m}^{3}\right)$ & 0.011 & 0.345 & 0.071 \\
\hline KAR & 0.31 & 0.26 & 0.22 & - & 0.007 & $<0.0001$ & 0.004 \\
\hline RW & 6.10 & 5.69 & 4.48 & $(\mathrm{~mm})$ & $<0.0001$ & $<0.0001$ & 0.094 \\
\hline GA & 4.0 & 3.6 & 3.4 & $(\%)$ & 0.48 & 0.29 & 0.71 \\
\hline \multicolumn{8}{|c|}{ Slow-grown stand, butt logs $(S-G-B L)$} \\
\hline & No.: 83 & 84 & 84 & & & & \\
\hline $\mathrm{f}_{\mathrm{m}}$ & 39.4 & 46.7 & 59.7 & $(\mathrm{MPa})$ & $<0.0001$ & $<0.0001$ & 0.0006 \\
\hline $\mathrm{E}$ & 10.4 & 11.8 & 13.9 & $(\mathrm{GPa})$ & $<0.0001$ & $<0.0001$ & $<0.0001$ \\
\hline DENS & 426 & 438 & 467 & $\left(\mathrm{~kg} / \mathrm{m}^{3}\right)$ & $<0.0001$ & $<0.0001$ & 0.0167 \\
\hline RW & 3.96 & 3.09 & 2.54 & $(\mathrm{~mm})$ & $<0.0001$ & $<0.0001$ & $<0.0001$ \\
\hline
\end{tabular}

Significance tests: P-values and mean values. Abbreviations: FG (fast-grown), $S G$ (slow-grown), $f_{m}$ (strength), $\mathrm{E}$ (modulus of elasticity), DENS (density), KAR (knot area ratio), RW (ring width) and GA (grain angle).

groups 16, 25 and 34 reveals that there is no difference between the 5 th percentile values for each group, see figure 5. This result indicates that some very 'poor quality' studs, which would normally be rejected, influenced the 5 th percentile for each group. In general, the knot area ratio (KAR) decreases from the pith to the bark [13]. However, the higher tail of the KAR distribution is very similar for all stud groups $(16,25,34)$. It is therefore rational to suppose that the lower tails of the bending strength distributions coincide fairly well for core, intermediate and mature studs.

\section{CONCLUSIONS}

There was a highly statistically significant difference between studs from the slow-grown and fast-grown stands when it came to both the modulus of elasticity and bending strength. In terms of mean values, the bending strength of studs from the slow-grown stand was $57 \%$ higher 

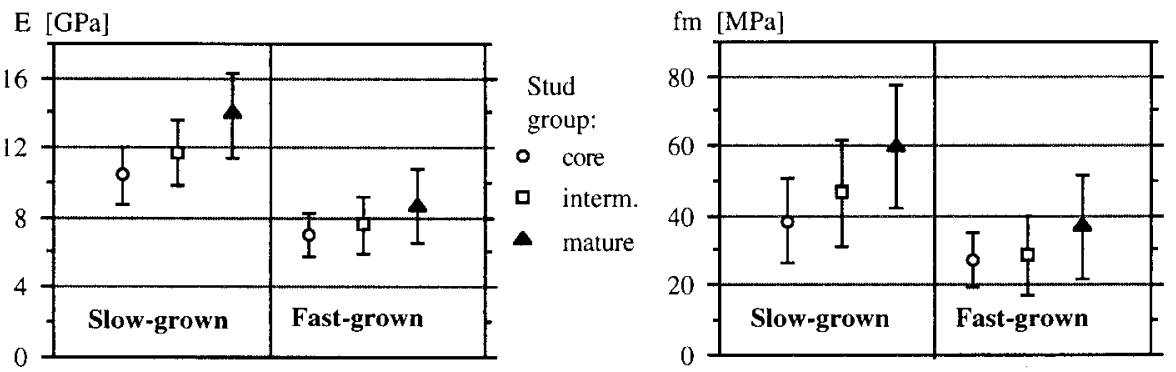

Figure 4. Modulus of elasticity $(E)$ and bending strength $\left(f_{m}\right)$ from studs sawn from three different radial positions: from mature wood (group 16), intermediate wood (group 25) and core wood (group 34).
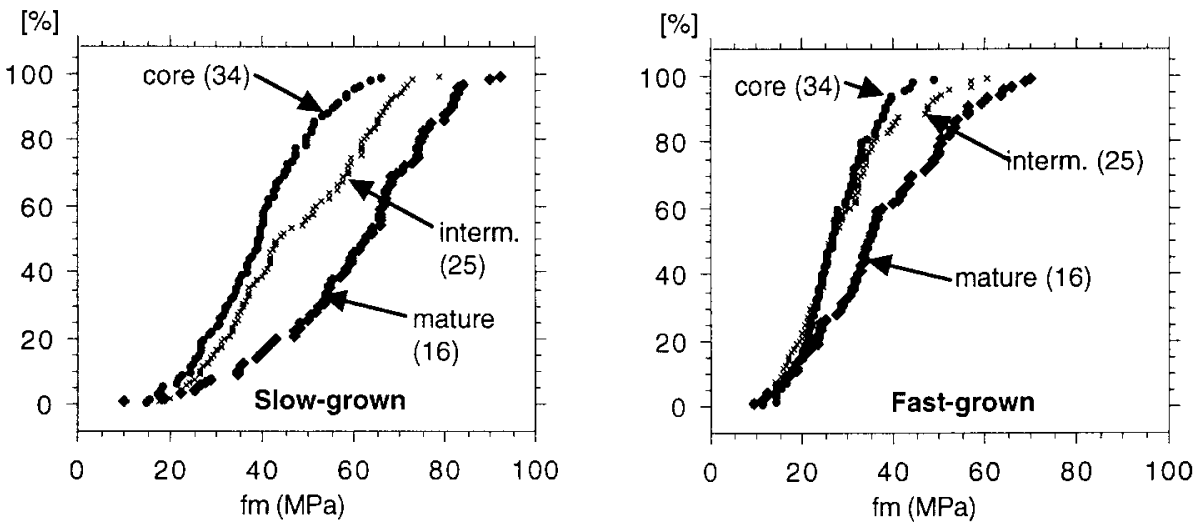

Figure 5. Percentile plots for strength (fm) divided into stud groups and slow-grown/fast-grown stands, respectively.
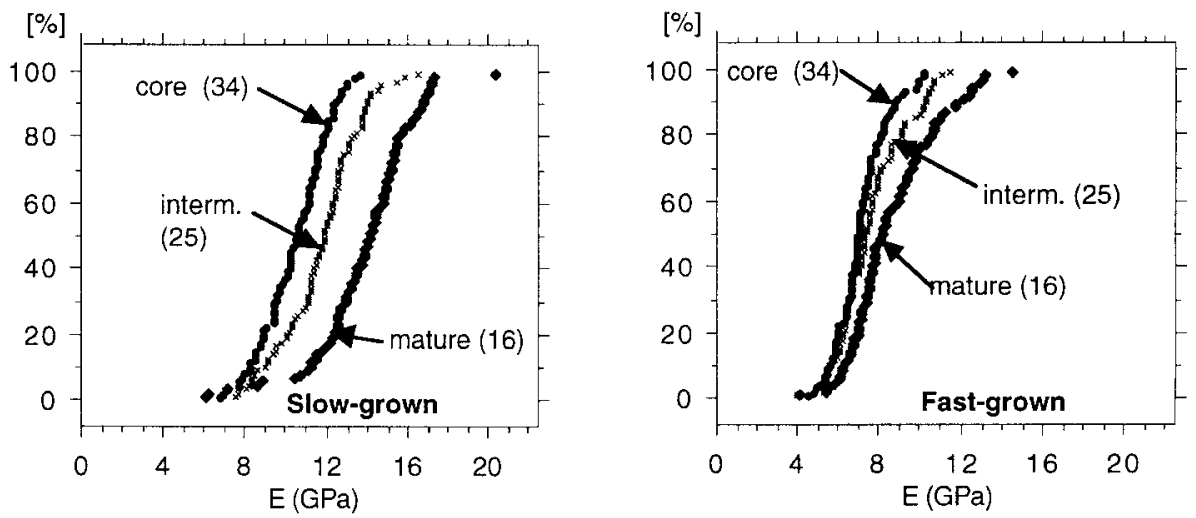

Figure 6. Percentile plots for modulus of elasticity (E) divided into stud groups and slow-grown /fast-grown stands, respectively. 

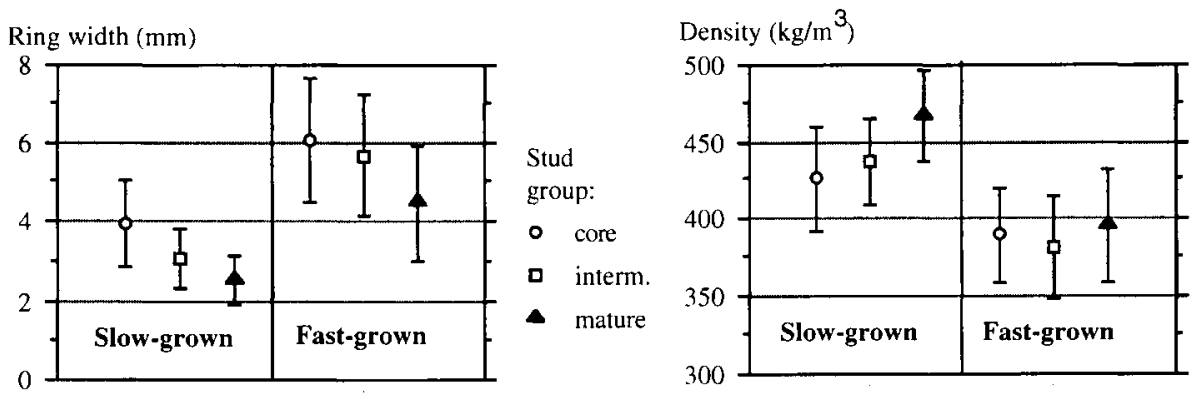

Figure 7. Ring width and density for studs sawn from three different radial positions: mature studs (group 16), intermediate studs (group 25) and core studs (group 34) divided into two stands - slowgrown and fast-grown.

and the modulus of elasticity $54 \%$ higher than that of studs from the fast-grown stand.

A clear radial variation in both the modulus of elasticity and bending strength was observed in the studs from the two stands divided into three different groups. In mean terms, the bending strength of the studs from mature wood (near the bark) was $47 \%$ higher and the modulus of elasticity $30 \%$ higher than that of the core studs. This increase in mechanical properties from the pith to the bark was far more significant for studs from the slowgrown stand than for studs from the fastgrown one.

\section{ACKNOWLEDGEMENT}

The authors gratefully acknowledge the financial support received from the EC forest research programme, Contract No. MA2BCT91-0024, Nils and Dorthi Troëdsson's Foundation, the Sawmills Research Foundation, the Swedish Sawmills' Association (Så bi), the Swedish National Board for Industrial and Technical Development (NUTEK) and, finally, Södra Timber AB.

The present paper was presented at the second workshop of the IUFRO Working Party S5.01-04: 'Connection between Silviculture and Wood Quality through Modelling
Approaches and Simulation Software', Kruger National Park, South Africa, August 1996.

\section{REFERENCES}

[1] Bendtsen B.A., Properties of wood from improved and intensively managed trees, Forest. Prod. J. 28(10) (1978) 61-72.

[2] Bendtsen B.A., Senft J., Mechanical and anatomical properties in individual growth rings of plantation-grown eastern cottonwood and loblolly pine, Wood Fiber Sci. 18(1) (1986) 23-28.

[3] Büsgen M., Münch E., The Structure and Life of Forest Trees, 3rd ed., John Wiley \& Sons, New York, 1929.

[4] Johansson C.J.. Brundin J., Gruber R., Stress grading of Swedish and German timber. A comparison of machine stress grading and three visual grading systems, Swedish National Testing and Research Institute Building Technology, SP Report 1992, 23.

[5] Kellogg R.M., Second growth Douglas fir: Its management and conversion for value, Forintek Canada Corp., special publication, SP-32, Vancouver, Canada, 1989.

[6] Kliger R., Johansson G., Perstorper M., Structural timber from large-dimension Norway spruce. Part 3: Stiffness and strength of wall studs (in Swedish). Chalmers University of Technology. Division of Steel and Timber Structures, Göteborg. Sweden, Publ. S 94:10. 1994.

[7] Kliger I.R., Perstorper M., Johansson G., Pellicane P.J., Quality of timber products from Norway spruce. Part 3: Influence of spatial position and growth characteristics on bend- 
ing stiffness and strength, Wood Sci. Technol. 29 (1995) 397-410.

18] Kliger I.R., Perstorper M., Johansson G., Variability in wood properties and its effect on distortion and mechanical properties of sawn timber, in: Proc. of CTIA/IUFRO International Wood Quality Workshop, Québec City, Forintek, Canada, 1997

19] Kretschmann D., Bendtsen B.A., Ultimate tensile stress and modulus of elasticity of fastgrown plantation loblolly pine lumber, Wood Fiber Sci. 24(2) (1992) 189-203.

[10] Lindström H., Wood variation in young Norway spruce (Picea abies (L.) Karst.) created by differences in growth conditions, Doctoral thesis, Silvestria 21, Swedish University of Agricultural Sciences, Uppsala, Sweden.

[11] Madsen B., Length effect in $38 \mathrm{~mm}$ spruce - pine - fir dimension lumber, Can. J. Civ. Eng. 17 (1990) 226-242.

[12] Nepveu G. (Ed.) Silvicultural control and non-destructive assessment of timber quality in plantation grown spruces and Douglas fir, final technical report, CEC Forest Project, Contract No. MA 2B-CT91-0024, Champenoux, France, 1994.
[13] Perstorper M., Pellicane P.J., Kliger I.R., Johansson G., Quality of timber products from Norway spruce. Part 1: Optimization, key variables and experimental study, Wood Sci. Technol. 29 (1995) 157-170.

[14] Shivnaraine C.S., Within stem variation in bending strength and stiffness of lumber from plantation grown white spruce, Univ. of New Brunswick, Wood Science and Tech. Centre, MSC thesis, Fredricton, Canada.

[15] Thörnqvist T., Juvenile wood in coniferous trees, D13, Swedish Council for Building Research, Stockholm, Sweden, 1993.

[16] Todoroki C.L., Developments of the sawing simulation software, AUTOSAW: linking wood properties, sawing and lumber end-use, in: Proc. of Second IUFRO (WP S5.01-04) Workshop in Kruger National Park, South Africa, 1996.

[17] Usenius A., Optimising models for predicting value yield in the sawmilling industry, in: Proc. of the Seminar on Scanning Technology and Image Processing on Wood, Skellefteă, Sweden, 1992.

[18] Xin T., Cown D., Modelling of wood properties, in: Proc, of Second IUFRO (WP S5.0104) Workshop in Kruger National Park, South Africa, 1996. 